secretary, Medical Council of India; Dr. C. W. B. Normand, director-general of observatories, Government of India ; Khan Bahadur Shapurji Nasarvanji Jamshedji Ratnagar, lately conservator of forests, Southern Circle, Bombay. C.B.E.: Mr. J. B. Beresford, secretary of the University Grants Committee and also of the Standing Commission on Museums and Galleries; Mr. J. Dewar, surveyorgeneral, Federated Malay States and Straits Settlements ; Mr. H. J. G. Griffin, secretary of the Council for the Preservation of Rural England; Mr. A. L. Hetherington, assistant secretary of the Department of Scientific and Industrial Research; Dr. J. W. Mellor, lately director of the British Refractories Research Association ; Dr. E. C. Snow, joint honorary secretary of the Royal Statistical Society ; Dr. A. H. Thompson, professor of history in the University of Leeds, and member of the Royal Commission on Historical Monuments (England).

O.B.E. : Captain T. W. Barnard, director of the Barnard Institute of Radiology, Madras; Mr. T. R. Charlton, commissioner of lands, Crown surveyor, and chairman, Mining Board, Fiji ; Mr. R. A. Farquharson, geologist in charge, Water-Boring Scheme, Somaliland Protectorate; Dr. R. S. G. Knight, manager and deputy superintendent, Royal Naval Cordite Factory, Holton Heath ; Mr. F. Leney, lately curator, Norwich Castle Museum and Art Gallery; Mr. H. M. O Lester, deputy director, Sleeping Sickness Service, Nigeria; Mr. W. B. Rimmer, acting director of the Solar Observatory at Mount Stromlo, Commonwealth of Australia; Ram Chandra Srivastava, director of the Imperial Institute of Sugar Technology, Cawnpore, United Provinces, India; Dr. V. E. Wilkins, principal, Ministry of Agriculture and Fisheries. M.B.E. : Mr. J. Coutts, lately curator, Royal Botanic Gardens, Kew; Mr. W. A. Fyffe, public analyst for the Isle of Man; Mr. W. B. Mercer, agricultural organizer for Cheshire and principal of the Reaseheath Farm Institute; Mr. A. E. Spencer, computor, Land and Survey Department, Uganda. Kaisar-i-Hind Gold Medal: Dr. R. R. Stewart, principal of Gordon College, Rawalpindi, Punjab.

\section{Indian Science Congress Association at Calcutta}

THE twenty-fifth annual meeting of the Indian Science Congress Association, to which the British Association has sent a large delegation, opened at Calcutta on January 3 under the presidency of Sir James Jeans. Lord Rutherford was to have been president, and that portion of the address which he had prepared, representing his final word on what he used to describe as "the new alchemy", is printed on pp. 58-61 of this issue of NaTuRE. Sir James Jeans made his address brief, so that he might read to the assembled Congress a portion of that prepared by Lord Rutherford. In the first part of his address, Sir James paid eloquent tribute to the man whose place he was filling-“one of the greatest scientists of all time". He spoke of his greatness, his simplicity and sincerity, and remarked on his genius for friendship and good comradeship, an aspect of Rutherford's character which has also been demonstrated in the tributes to his memory we have been privileged to publish. In spite of the honours showered upon him, he was always "unassuming and ready to listen patiently to even the youngest and most inexperienced of his pupils or fellow-workers". Speaking of the work he accomplished, Sir James said that, "in his flair for the right line of approach to a problem, as well as in the simple directness of his methods of attack, he often reminds us of Faraday, but he had two great advantages which Faraday did not possess - first, exuberant bodily health and energy, and second, the opportunity and capacity to direct a band of enthusiastic co-workers. Great though Faraday's output of work was, it seems to me that to match Rutherford's work in quantity as well as in quality, we must go back to Newton".

\section{Progress of Science in India}

In the second part of his address, Sir James Jeans referred to the progress of science during the quarter of a century since the Congress was founded, and to the contributions of Indian workers. Restricting himself to the field of mathematics and physics, he mentioned the remarkable discoveries made in pure mathematics by Ramanujan in his short life; the work of Sir Venkata Raman in sound and the theory of music, and his discovery of the spectral effect now known everywhere by his name; the investigations of Prof. M. Saha in astrophysics, "which gave us our first clear understanding of the meaning of stellar spectra, and so unlocked the road to vast new fields of astronomical knowledge" ; and also the work of many Indians, especially Chandrasekhar and Kothari, on conditions in the interiors of stars. Many, other than mathematicians and physicists, would also be thinking of the great experimental skill of the late Sir Jagadis Chandra Bose. In 1911, Sir James said, there were no Indian-born fellows of the Royal Society; now there are four. In 1911, the Royal Society published no papers by Indians ; in 1936, the Society published ten. The past twenty-five years have been one of the greatest periods in the history of science, a period of unprecedented progress in which India has taken its part and which has seen the remarkable growth of India as a scientific nation.

\section{Policy and the Aborigines in Australia}

IT is to be hoped that no apparent difference of opinion among anthropologists as to the ultimate fate of the Australian aborigines will be allowed to obscure the plain present duty of the Commonwealth Government in the matter of reform of policy and methods of administration. The report of $\mathrm{Dr}$. Donald F. F. Thomson, research fellow of the University of Melbourne, to the Commonwealth Government on his observations as a special patrol officer for a period of fifteen months among the natives of Arnhem Land in the Northern Territories is uncompromising in its directness. $\mathrm{H} \Theta$ recommends, according to a dispatch of the Canberra correspondent of The Times in the issue of December 30, that the remains of the tribalized natives of the Northern Territories, who come under the control of the Commonwealth Govern- 